\title{
Towards One Voice in Beijing? The Role of the EU's Diplomatic Representation in China Over Time
}

\author{
Frauke AUSTERMANN
}

\section{Introduction: Speaking with One Voice in Beijing?}

The European Union's difficulty to speak with one voice is said to be particularly problematic when it comes to relations with the People's Republic of China (PRC). ${ }^{1}$ The disunity about the arms embargo on China or about the PRC's Market Economy Status testify to this. China has become too important a player in global politics. The national interests of EU member states are too pronounced and diverse for the EU to act as one entity towards the rising power in the East. ${ }^{2}$

The EU member states have taken a bold step in order to mitigate their inability to speak with one voice. The Treaty of Lisbon, which came into force on 4 December 2009, has created the post of High Representative of the Union for Foreign Affairs and Security Policy. ${ }^{3}$ The powers of the British noblewoman Catherine Ashton, who is the first to fulfil this role, are comparable to those of a minister for foreign affairs. The EU member states were nevertheless eager to tone down Ashton's title from

1. This article builds upon the author's previous work, which was presented during the research seminar EU Diplomacy after Lisbon: The Case of China, a joint event by the EU Centre in Singapore and the East Asian Institute at National University of Singapore (NUS) on 7 December 2010 (see http:// eucentre.sg/details.php?j=240). The author sincerely thanks the EU Centre and the East Asian Institute, the seminar's participants, and especially Dr. Bo Zhiyue for their support and valuable feedback. The main argument has been briefly summarised in the following article: F.AUSTERMANN, One Voice in Beijing? EU Diplomacy One Year After Lisbon, 13.12.2010, http://euobserver.com/ 7/31488 (retrieved 17.12.2011). The author also expresses her gratitude to the Dahlem Research School for the generous financial support.

2. J. FOX, F. GODEMENT, A Power Audit of EU-China Relations, European Council on Foreign Relations, London, 2009, p.30.

3. EUROPEAN COUNCIL, Implementation of the Lisbon Treaty - Appointments, 17163/09 (Presse 368), Brussels, 4 December 2009, p.1, http://www.consilium.europa.eu/uedocs/cms_data/docs/pressdata/en/gena/111771.pdf (retrieved 31.08.2011). 
'Union Minister for Foreign Affairs' as foreseen in the failed Constitutional Treaty to a mere 'High Representative'. ${ }^{4}$

Beyond such semantic disputes, Ashton is not a "one[wo]man-band" like her predecessor Javier Solana. ${ }^{5}$ She now directs close to 150 EU Delegations and other Union offices which function like an embassy-like network. ${ }^{6}$ These Delegations represent the European Union towards third countries and are key to maintaining and to strengthening the Union's diplomatic ties. Yet, the Delegations are no new invention. The Commission has started developing a worldwide network of representations as early as $1954 .^{7}$ Due to the existing infrastructure and the long-standing field expertise of these offices, it was convenient for Ashton to use them as her prototype Unionembassies. ${ }^{8}$

Most Commission Delegations started off as mere information offices or as agencies implementing development projects. Over the past decades, they have taken over more and more classical diplomatic tasks. With the Lisbon Treaty, they now have the exclusive right to represent the EU towards their host countries. ${ }^{9}$

The terms of a Treaty are one side of the coin; practical implementation is another issue. Given the difficulty of the European Union to speak with one voice towards China, Beijing provides a strong testing ground for the diplomatic role of the EU in third country capitals. By tracing the development of the EU's diplomatic representation in the PRC over time, this paper sheds a different light on the EU-China relationship and the nascent EEAS. It reveals that the Union has been increasingly capable of centralising European diplomacy 'on the ground'. Despite certain limitations, the

4. According to the Constitutional Treaty, Ashton would have carried the title of the 'Union's Minister for Foreign Affairs'. Although the title has been changed, most institutional powers have remained, also with the Lisbon Treaty. See: EUROPEAN UNION, A Constitution for Europe, The Institutions of the Union, http://europa.eu/scadplus/constitution/minister_en.htm (retrieved 31.08.2011); EUROPEAN UNION, Consolidated Versions of the Treaty on European Union and the Treaty on the Functioning of the European Union, Art. 18, in: Official Journal, 53, 2010/C 83/26. See also: J. WOUTERS, The Union Minister for Foreign Affairs: Europe's Single Voice or Trojan Horse?, Opinions. Institute for International Law, Catholic University Leuven, 2004, p.1. https://www.law.kuleuven.be/iir/nl/onderzoek/opinies/JWeuMFAjuli04.pdf (retrieved 31.08.2011); A. SHAFIQ, Political Reform in the European Union: The Treaty of Lisbon, Institute of Strategic Studies, Islamabad, 2007, http://www.issi.org.pk/publication-files/1302769483_55478188.pdf (retrieved 31.08.2011).

5. B. HOCKING, D. SPENCE, Towards a European Diplomatic System? Discussion Papers in Diplomacy, Netherlands Institute of International Relations 'Clingendael', The Hague, 2005, p.4.

6. Counted by the author on the basis of EU Delegation websites (May 2011). EUROPEAN UNION, Consolidated Versions of the Treaty ..., op.cit., Art. 221.2.

7. Cf. D. SPENCE, The European Commission's External Service, in: Public Policy and Administration, 3(2004), p.61.

8. J. MORAN, F. PONZ CANTO, Taking Europe to the World. 50 Years of the European Commission's External Service, European Commission DG External Relations, Office for Official Publications of the European Communities, Luxembourg, 2004, pp.6 and 36, http://ec.europa.eu/external_relations/ delegations/docs/50_years_brochure_en.pdf(retrieved 31.08.2011).

9. Interview with a European diplomat on September 12, 2011, in Beijing; COUNCIL OF THE EUROPEAN UNION, Council Decision Establishing the Organisation and Functioning of the European External Action Service, Art. 5(8), 26.07.2010, in: Official Journal, 03.08.2010. 
analysis testifies to the widening and deepening of EU integration, even concerning diplomatic representation, the supposedly last stronghold of high politics.

\section{Widening and Deepening: The Role of the Commission-/EU Delegation in China Over Time}

With globalisation, distances shrink and virtual meetings complement or even replace physical ones. This is also true for diplomacy. In the history of international relations, emails and video-conferences have been mere science-fiction until recently. Today, however, thanks to these means of communication permanent representations in other countries, such as embassies and consulates may seem less important. Nevertheless, virtual contacts lack the qualities of face-to-face meetings. This is particularly true for the field of diplomacy which is a highly secretive endeavour that requires trust. This trust can best be established through personal contacts.

Diagram 1: EU Diplomatic Representation in Comparison ${ }^{10}$

EU Diplomatic Representation in Comparison

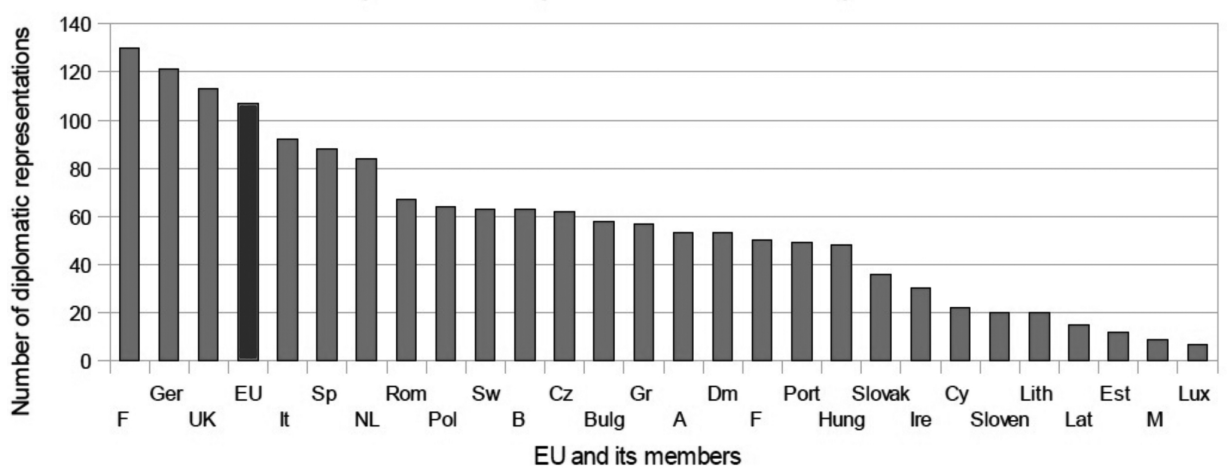

Additionally, the leaked diplomatic cables published by WikiLeaks have made the risks of virtual communication clear. ${ }^{11}$ Also, seeing the conditions in a given country

10. Compiled by the author based on EU Delegation websites and websites of member state foreign ministries and embassies (accessed in February/March 2011). For the sake of comparison, only fullyfledged embassies (i.e. no consulates etc.) and EU Delegations to sovereign states outside the current EU-27 were taken into account (i.e. excluding firstly, embassies of one EU member state to another; secondly, permanent representations to international organisations; and thirdly, representations to disputed territories, such as Palestine).

11. I. NEUMANN, Globalisation and Diplomacy, Working Paper No.724, Norwegian Institute of International Affairs, Oslo, 2007, p.8; E. ROCCO, Trust Breaks Down in Electronic Contexts but Can be Repaired by Some Initial Face-to-Face Contact, Paper presented during CHI 98 Conference on Human Factors in Computing Systems, Los Angeles, April 1998, pp.496-502; International Institute for Strategic Studies, WikiLeaks: The Price of Sharing Data, in: Strategic Comments, 1(2011), pp. 1-3. 
for oneself improves the evaluation of the exact situation and facilitates connecting home and abroad. It therefore remains advantageous to support diplomatic relations by maintaining a physical presence abroad. Despite not being a nation-state, the EU champions diplomatic representation. In terms of network-size, it ranks fourth compared to the 27 Union members.

As EU Delegations co-exist with member state embassies, third country capitals constitute a microcosm of EU foreign policy coordination, far away from Brussels. By historically tracing the role of Commission/EU Delegations generally and particularly in Beijing, I argue that they have become the central players in coordinating and representing European diplomacy abroad. This does not only apply to trade or environmental matters but also to 'high politics', i.e. traditional nation-state-based diplomacy and even security issues.

Jean Monnet, one of the founding fathers of the European Union, already claimed that the Community needed an identity abroad..$^{12}$ In line with Monnet's doctrine of incrementalism, the network of Community offices abroad grew in waves and not according to a federalist master plan. ${ }^{13}$ This is illustrated in Diagram 2.

There are EU external and internal triggers to this development. Externally, it is a function of the (changing) relations of Union members with third countries. Taking a look at the first prototype Delegations illustrates this. Two years before opening a mission of the European Coal and Steel Community (ECSC) in London, the very first office truly outside of Europe was established in Washington DC in $1954 .{ }^{14}$ This reflects the close relationship between the ECSC founding members and the US. Ten out of all twelve Commission Delegations which opened in the 1960s were located in Africa. ${ }^{15}$ This mirrors post-colonial interests of member states such as France. Internally, the Delegations' development is linked to advances in European integration. The establishment of new offices followed major treaty revisions or agreements at Community level. The Single European Act, a major step in European (economic) integration, therefore sparked off a wave of new EC offices in capitals of (potential) trading partners. The Delegation in Beijing which was opened in 1988 is one example.

12. J. MORAN, F. PONZ CANTO, op.cit., p.11.

13. M. BURGESS, Federalism and Federation, in: M. CINI (ed.), European Union Politics, Oxford University Press, Oxford, 2007, p.79; D. SPENCE, op.cit., p.61. Cf. also a telephone interview with a European diplomat on September 19, 2011.

14. D. SHAMBAUGH, E. SANDSCHNEIDER, H. ZHOU, China-Europe Relations: Perceptions, Policies and Prospects, Routledge, Oxon, 2008, chap. From Honeymoon to Marriage. Prospects for the China-Europe Relationship, pp.306-308; M. BRUTER, Diplomacy without a State: The External Delegations of the European Commission, in: Journal of European Public Policy, 2(1999), p.183.

15. Calculated by the author on the basis of European Commission information (websites, email and telephone correspondence in spring 2011). 
Diagram 2: Commission/ EU Delegations and Offices in Third Countries Over Time ${ }^{16}$

\section{Commission/EU Delegations and Offices in Third Countries}

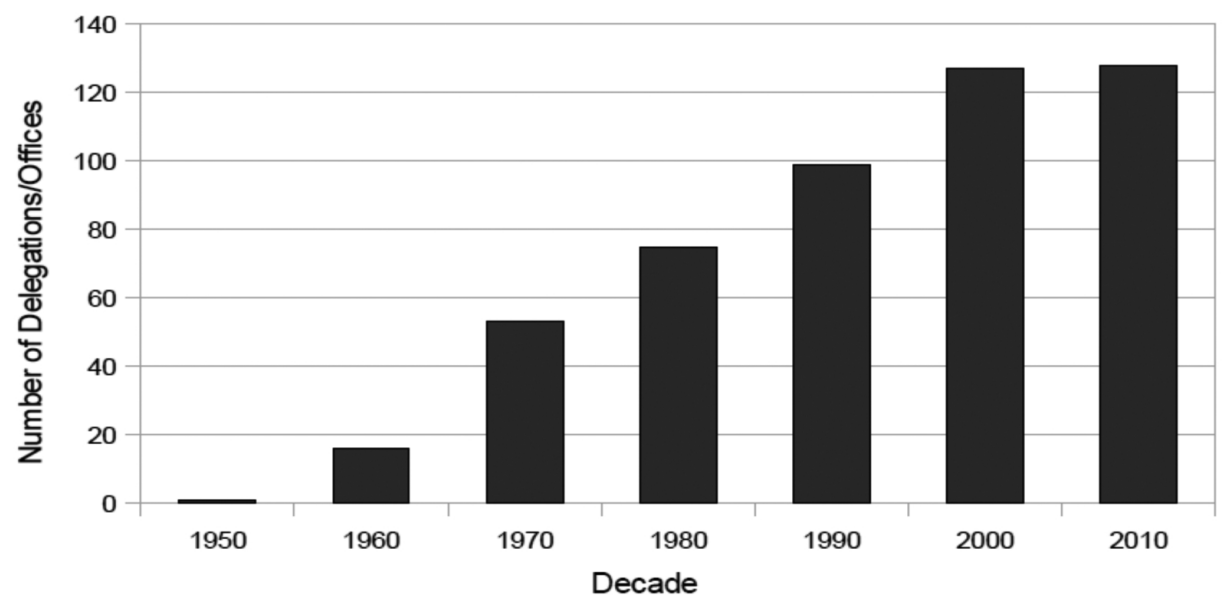

A third trigger for the widening and deepening of the Union's presence in the world is the "ability of political leaders". ${ }^{17}$ Back in the early 1970s, European Commissioner for External Relations Lord Christopher Soames, Chinese Premier Zhou Enlai, and Trade Minister Yao Yilin brought the EC and the PRC closer together. ${ }^{18}$ Initially, the Commission sought to establish relations with state trading countries, such as the USSR, Cuba, Vietnam and the PRC. The PRC was the only country to accept the invitation. The reason was highly political as the Chinese leadership considered the EC a potential geopolitical counterweight to transform the global bi-polar structure into a multi-polar one. ${ }^{19}$ Consequently, the PRC recognised the EC 20 years before the Soviet Union/Russian Federation. Nevertheless, 'low politics' filled Sino-European diplomatic relations with life. This only happened in the mid-1980s. Commission President Jacques Delors quickly realised the potential of Deng Xiaoping's economic reforms. Deng for his part must have taken note of developments within the EC, notably the preparations for the Single European Act and the Southern enlargement. Respectively, China and the EC codified relations in the 1985 Trade and Co-

16. Compiled by the author based on EU Delegation websites and correspondence with EU staff (between February and April 2011). For the sake of comparison, only EU representations to sovereign states outside the current EU-27 were taken into account (i.e. excluding firstly former Commission/ EU Delegations to previous non-EU-members; secondly Commission/EU representations to international organisations; and thirdly, Commission/EU representations to disputed territories, such as Palestine).

17. D. SHAMBAUGH, E. SANDSCHNEIDER, H. ZHOU, op.cit., pp.306-308.

18. P. DUCHATEAU, La Chine et l'Europe, in: Revue du Marché Commun et de l'Union Européenne, 474(2004), p.10.

19. Interview with a European diplomat on September 12, 2011, in Beijing; [Major Events in EU-China Relations], Xinhua Online, 29.09.2010, http://www1.china.com.cn/international/txt/2010-09/29/ content_21034963.htm (retrieved 31.08.2011). 
operation Agreement. The opening of a Commission Delegation in Beijing three years thereafter "was a logical consequence". ${ }^{20}$

Not only did the EC increase the number of offices abroad. It also incrementally equipped them with more tasks, rights and increasingly professional staff. Starting in the 1970s, more and more Delegations enjoyed full diplomatic status and protection, long before the set-up of the Common Foreign and Security Policy (CFSP). Also, the contract staff was largely replaced by Commission officials. Yet, the Commission still lacked the professionalism of national diplomatic services. Also, the Heads of Mission (HOMs) were not yet on par with the member state Ambassadors. As the Lisbon Treaty has transformed Commission Delegations into Union Delegations, the HOMs now carry the official title 'European Union Ambassadors' ${ }^{21}$ By now they certainly constitute an integral part of the community of European diplomats abroad.

Let us now take a closer look at the Commission/EU Delegation in Beijing. As leadership is key to understand EU external relations, we will analyse the terms of each of the five EU Ambassadors to China in turn, from 1988 until today. EU internal developments and external triggers that widened and deepened the role of the Union's presence in Beijing will be embedded in the analysis. The study of the Delegation includes the Ambassadors' profiles; the main tasks and human resources during each period; the relationship between the Delegation and the local member state embassies; and the Delegation's role vis-à-vis the Chinese authorities. The analysis is backed by a rich variety of primary sources, such as original Commission/EU documents, newspaper articles, as well as interviews with diplomats from Europe and China.

\section{8-1994: Head of Delegation Pierre Duchâteau}

The first Head of the Commission Delegation was Pierre Duchâteau. He led the Beijing representation from 1988 until 1994. With 30 years of work experience in the Commission, he knew Brussels from the inside out. The lawyer and son of a French diplomat spent the first years of his career at Euratom and in the executive floor of the Commission. In 1974, he became the Europe-Director of the External Relations

20. Email correspondence with a European diplomat on July 8, 2011; Interview with a European diplomat on September 12, 2011, in Beijing; Telephone interview with a European diplomat on September 19, 2011; COUNCIL OF THE EUROPEAN UNION, Council Regulation concerning the conclusion of a Trade and Economic Cooperation Agreement between the European Economic Community and the People's Republic of China, in: Official Journal, 19.09.1985.

21. V. DIMIER, M. MCGEEVER, Diplomats Without a Flag: The Institutionalization of the Delegations of the Commission in African, Caribbean and Pacific Countries, in: Journal of Common Market Studies, 3(2006), pp.483-505; J. MORAN, F. PONZ CANTO, op.cit., pp.32-33, 44; D. SPENCE, op.cit., p.65; Interview with a European diplomat on September 12, 2011, in Beijing; EU Delegation to China and Mongolia, European Union Enters New Era as Treaty of Lisbon Comes into Effect on Dec 1, 25.11.2009, http://eeas.europa.eu/delegations/china/press_corner/all_news/news/ 2009/20091125_03_en.htm (retrieved 06.09.2011). 
Directorate. A decade later he embarked on his first ambassadorial post to the OECD in Paris. The job as Head of Delegation in Beijing was his last posting before retirement. 22

Duchâteau and his successors' seniority makes clear that Brussels attached much importance to the EC's presence in Beijing. Already back then it seemed common to call the Head of the Commission's Delegation 'EU/EU Ambassador'. Duchâteau was positively received by the Beijing-based European Ambassadors. The quality of this relationship however heavily depended on Duchâteau staying in his territory of competences. He and the Delegation staff were experts in commercial, agricultural and development policy. The member state Ambassadors by contrast were clearly in charge of political matters. ${ }^{23}$

Nevertheless, trespassing into a 'forbidden territory' became possible in practice, for example at the occasion of the weekly meetings of the EC member state Ambassadors. During these meetings, Duchâteau 'traded' information on the Chinese position concerning WTO accession for political information. He thereby achieved full involvement in the Troika meetings. But the events at Tiananmen Square in 1989 made the limitations clear again: the EC-PRC economic dialogue was not resumed until the member states agreed to unfreeze political contacts to the PRC. Delors wanted to mitigate such barriers and asked Duchâteau to prepare a meeting with the PRC's Foreign Minister of the time, Qian Qichen. After a year of negotiations, Duchâteau and his team managed to bring Qian to Brussels. This strengthened the political dimension of the EU-China relationship. Nevertheless, over 90 percent of the Delegation's funds were used for the so-called EU-China Dairy Project, which was basically an "effort to reduce Europe's milk powder mountains". ${ }^{24}$

Practically, the Beijing Delegation already functioned as a local manager and mediator of the European Parliament's (EP) delicate relations with the PRC. Legally, this function was only stipulated 20 years later. ${ }^{25}$ In December 1992, the EP adopted a resolution in which it strongly criticised the human rights situation in Tibet. Even though Pierre Duchâteau only represented the Commission, he was summoned by the PRC's Foreign Ministry (MOFA). It was also the Head of the Commission Delegation whom the Chinese government officially invited to visit Lhasa in order to "check the accusations made by Parliament". Duchâteau was accompanied by eleven other EU member state Ambassadors when the trip took place in May 1993. He

22. Historical Archives of the European Union [henceforth: HAEU], European Oral History, All Programmes of Interviews, European University Institute, Florence, 1994-2009, p.114. Ibid.

23. Cf. Telephone interview with a European diplomat on September 19, 2011; P. DUCHATEAU, op.cit., p.10. HAEU, Histoire Interne de la Commission Européenne 1958-1973, Interview with Pierre Duchâteau by Yves Conrad and Anais Legendre on December 12, 2003, Catholic University Leuven, Brussels, p.22.

24. European Commission, internal document, September 1995, p.1; Interview with a European diplomat on September 12, 2011, in Beijing.

25. P. DUCHATEAU, op.cit., p.12; COUNCIL OF THE EUROPEAN UNION, Council Decision ..., op.cit., Art. 5(7). 
thereby led the "highest level foreign delegation" since the PRC allowed political delegations to visit Tibet. ${ }^{26}$

\section{4-2001: Head of Delegation Endymion Wilkinson}

Shortly thereafter, Duchâteau retired and the British Endymion Wilkinson took over. Wilkinson had about ten years less work experience in the European Commission than Duchâteau at the time of arriving in Beijing. ${ }^{27}$ However, in the person of Wilkinson a reputable China-expert was to head the Delegation for the following six years. Endymion Wilkinson had entered the Commission in 1974 and became in the same year the first chargé d'affaires of the Commission Delegation in Tokyo. Only one year later he accompanied Commissioner Soames to Beijing to establish EU-China diplomatic relations. ${ }^{28}$

Similar to his predecessor, he was already referred to as the 'EU Ambassador' or the 'EU Representative' in newspapers and reports. ${ }^{29}$ Whereas the Commission itself refused to call its Heads of Delegation 'Ambassadors', Wilkinson presented his credentials to the PRC's Head of State, just like the member state Ambassadors. He was also a very respected colleague, not least because of his knowledge of China and his Mandarin skills.

Especially in the aftermath of 1989, the profile of the EC and its Delegation in the PRC was quite low. Suitable premises for the Commission Delegation first had to be organised and the Delegation personnel had to be reshuffled. This cumbersome task reflects that the Commission still lacked professionalism in managing its overseas offices. Moreover, the EC was "barely known" to the Chinese people. They at best associated it with the aforementioned milk project. It was therefore decided to di-

26. R. BARNETT, High Level Commission Delegation to Visit Lhasa May $17^{\text {th }}$ to $22^{\text {nd }}$, Tibet Information Network, Montreal, 08.05.1993, http://www.tibet.ca/en/newsroom/wtn/archive/old? $\mathrm{y}=1993 \& \mathrm{~m}=5 \& \mathrm{p}=8-2 \_1$ (retrieved 01.09.2011).

27. EUROPEAN SOCIETY PEKING UNIVERSITY (EUS), [Members of European Society (EUS) Meet With Former EU Ambassador Prof. Endymion Wilkinson], 20.10.2006, http://web5.pku.edu.cn/euc/chnhome/061025.htm (retrieved 02.09.2011).

28. HARVARD BUSINESS SCHOOL, Transition. Exploring China's Path Forward, Harvard China Review, Sixth Annual Conference, 12.04.2003, http://harvardchina.org/www/backup/conference/ conf2003/speakers.html\#WilkinsonEndymion (retrieved 02.09.2011); S. KAWASAKI, Diplomatic Relations between Japan and the European Communities, Ministry of Foreign Affairs of Japan, Tokyo, 01.01.2009, http://www.mofa.go.jp/mofaj/press/pr/pub/geppo/pdfs/09_1_1.pdf (retrieved 02.09.2011); TSINGHUA UNIVERSITY LIBRARY, Túshü guăn jǔxing wèi gēnshēēn jiàoshòu zèng shü yishì, Tsinghua University, Beijing, 14.07.2005, http://oldweb.lib.tsinghua.edu.cn/homepage/ wenku_view.jsp?id=1623 (retrieved 02.09.2011); Interview with a European diplomat on September 12, 2011, in Beijing.

29. EU, China to Resume WTO Talks "Very Shortly": EU envoy, 18.04.2000, in: People's Daily, http:// english.peopledaily.com.cn/english/200004/18/eng20000418_39162.html (retrieved 20.09.2011); A. REYES, Gearing Up for WTO, in: Asia Week, 25.04.2000, http://edition.cnn.com/ASIANOW/ asiaweek/foc/2000/04/25/ (retrieved 20.09.2011). 
versify and to raise the profile of the EC in China. The main areas next to agricultural cooperation were education, business cooperation, the environment, legal cooperation, information and media, and democracy in rural areas. ${ }^{30}$ The implementation of these goals was project-based. Despite resistance from Europe, where China still ranked low on politicians' agendas, about 40 different projects were launched worth 250 million ECU. ${ }^{31}$ A well known example is the China Europe International Business School (CEIBS) which is now among the top business schools worldwide. Moreover, primary schools in Gansu province were modernised with EC-money. The Delegation also helped the city of Shenyang to develop its tourism industry. In addition, the EU emerged as a leader in the field of environmental protection in China. ${ }^{32}$

The Delegation's increasing profile was firmly based on the flourishing trade relations between the EU and China rather than on traditional high politics. Ambassador Wilkinson was a frequent guest in the Ministry of Commerce but more rarely seen in the MOFA. This does not come as a surprise as China had become the EU's fourth biggest trading partner. More importantly, during Wilkinson's term, China applied for membership in the World Trade Organisation (WTO). The accession negotiations 'on the ground' were dealt with by the Commission Delegation, not by the single member state embassies. ${ }^{33}$ Trade matters thus kept dominating the Delegation's portfolio and it clearly did not deal with certain 'high political' matters, such as consular or military affairs. Yet, the fact that then Trade Commissioner Pascal Lamy and Endymion Wilkinson enjoyed the Union members' "total support" to handle the WTO negotiations gave the Delegation the edge to do more. ${ }^{34}$ Through the many projects it gained an expertise in a growing number of policy domains. This raised the Delegation's potential as a general coordinating force of European diplomacy in Beijing. In fact, Ambassador Wilkinson considered it his main task to make clear to the Chinese authorities that there are common European interests. Thus, the Delegation's coordinating role increased and did not limit itself to trade policy. After

30. Interview with a European diplomat on September 12, 2011, in Beijing; European Commission, internal documents, March 1995, p.2 and September 1995, p.2.

31. Before 1994, the Commission Delegation spent most of its budget (about 40 Million ECU) on agricultural cooperation. See: Interview with a European diplomat on September 12, 2011, in Beijing.

32. China-Europe International Business School, CEIBS Establishment, http://www.ceibs.edu/today/ establishment/chinaeu/index.shtml (02.09.2011); Business School Rankings, in: Financial Times, http://rankings.ft.com/businessschoolrankings/ceibs/global-mba-rankings-2011\#global-mba-rankings-2011 (retrieved 20.09.2011); Sino-EU Environment Project Launched in Liaoning, in: People's Daily, 11.12.1999, http://english.peopledaily.com.cn/english/199912/11/eng19991211B108.html (retrieved 02.09.2011); Project to Reduce China's Vehicle Emission, in: People's Daily, 10.11.2000, http://www.china.org.cn/english/2000/Oct/2693.htm (retrieved 02.09.2011).

33. Interview with a Chinese diplomat on July 19, 2011, in Beijing; P. LE CORRE, L'Europe se ferat-elle en Chine?, in: Perspectives Chinoises, 31(1995), p.20; Interview with a European diplomat on September 12, 2011, in Beijing.

34. [Economic Storm], in: Building the New Economy: What Does WTO Mean for China?, October 2000, http://www.shu.edu.cn/Admiss/guoshang/oldpage/ST/contemporary/ce0010013.htm (retrieved 02.09.2011). 
all, economics and politics are "in practice [...] indivisible". ${ }^{35}$ This reflects an upcoming task role of the Commission Delegation to China back at that time, which consisted in implementing a major goal of the Maastricht Treaty: a 'Common' Foreign and Security Policy.

In line with the incremental spill-over logic, which explains much of the EU's development since its beginnings, the Delegation's development consisted of incremental, pragmatic steps. To advance the CFSP 'on the ground' more high-level political coordination was necessary, e.g. through visits of the EU Presidency. But the organisation of visits has been and continues to be one of the most time-consuming jobs for embassies and for Commission/EU Delegations alike. ${ }^{36}$ Although the number of European officials in the Delegation had grown from 7 in 1994 to 13 in 2000, this was not an easy task. ${ }^{37}$

\section{1-2005: Head of Delegation Klaus Ebermann}

Under the next Ambassador, Klaus Ebermann, the Delegation-staff immediately doubled, which was mainly due to the deconcentration policy. This policy gave Delegations worldwide much more leeway to implement their projects. With the increased manpower, representative tasks could be handled more easily, too, such as the visits of as many as eight European Commissioners to Beijing in 2003. ${ }^{38}$ For his own first visit to Europe in May 2004, the PRC's Prime Minister Wen Jiabao reserved ten days. The EU's headquarters in Brussels were his final stopover. With flourishing personal relations of the leaders on both sides and without major critical political events, the EU-China relations underwent a "golden period" during Ebermann's term. The Ambassador not only called the EU and China "trading partners" but also "best friends". Nevertheless, the good relations were still anchored in economics. In 2003, China was the EU's third most important trading partner while the EU ranked second

35. European Commission Delegation to China and Mongolia, Public Statement of Objectives, 1994; P. LE CORRE, op.cit., p.20-21; European Commission, internal document, March 1995, pp.1-6; Interview with a European diplomat on September 12, 2011, in Beijing.

36. E. HAAS, Beyond the Nation-State: Functionalism and International Organization, Stanford University Press, Stanford, 1964; Email correspondence with a European diplomat on 08.07.2011.

37. NB: One of the seven European officials only worked part time for the Beijing Delegation. See: Interview with a European diplomat on September 12, 2011, in Beijing; C. ASHTON, Staff in Commission Delegations, Answer to Parliamentary Question by MEP Ingeborg Gräßle from September 7, 2009, Given by Baroness Ashton on Behalf of the Commission, Annex tables, Brussels, 17.12.2009, http://www.europarl.europa.eu/sides/getAllAnswers.do?reference=E-2009-4251\& language $=\mathrm{EN}$ (retrieved 02.09.2011).

38. Telephone interview with a European diplomat on September 19, 2011; The China News Digest, Sino-EU Relationship to Benefit from Growth, April 2004, http://thechina.biz/china-economy/sinoeu-relationship-to-benefit-from-growth/ (retrieved 02.09.2011). 
for China, after the US..$^{39}$ The Commission Delegation in China was moreover leading in implementing rules and regulations following China's WTO accession. ${ }^{40}$ Another factor was the upcoming enlargement. Consequently, the EU became China's top trading partner in 2005. This clearly raised the Delegation's profile and strengthened the bonds between Commission staff in Beijing and Chinese governmental officials. $^{41}$

Building upon this advantageous position, Ebermann sought to foster the Delegation's professionalism and its political dimension. He hired a deputy Head of Mission from the Commission's middle management layers and promoted the Sino-EU relationship as being "much more than a simple trade in goods". Regarding Beijing's diplomatic list, he managed that the Commission Delegation was put into the same category as the EU member states and not amongst the international organisations.

When Ebermann arrived in Beijing he had served 27 years within the Commission. Throughout his career, the lawyer and economist held positions similar to Duchâteau, such as in the Commission Cabinet and in the External Affairs Directorate. Between 1984 and 1988 he was in charge of managing and professionalising Delegations worldwide. During this time he also negotiated the accord du siège for the Commission Delegation to China. Beijing was however Klaus Ebermann's first posting as Head of Delegation. ${ }^{42}$ Under his command, previous projects were continued and expanded, notably in the area of science and technology. These projects were not only

39. China Radio International, Chinese Premier Leaves for Europe Visit, 02.05.2004, http://www.china.org.cn/english/2004/May/94552.htm (retrieved 02.09.2011); Q. WANG, EU Delegation in Beijing Celebrates Europe Day, in: China.org.cn, 12.05.2004, http://www.china.org.cn/english/international/95216.htm (retrieved 02.09.2011); We Are the Best Friends - An Interview with Mr. Klaus Ebermann, EU Ambassador to China, in: People's Daily, 09.06.2004, http://english.peopledaily.com.cn/200406/10/eng20040610_145870.html (retrieved 02.09.2011).

40. Cf. K. EBERMANN, Speech at the China Investment Forum in Beijing, 07.12.2001, http:// www.china.org.cn/english/international/95216.htm (retrieved 02.09.2011).

41. People's Daily Online, EU Becomes China's Largest Trading Partner, 10.01.2005, http://news.xinhuanet.com/english/2005-01/10/content_2439568.htm (retrieved 05.09.2011); Telephone interview with a European diplomat on September 19, 2011.

42. British University in Egypt, HE Klaus Ebermann, Former Ambassador of the European Commission Delegation at BUE, n.d., http://www.bue.edu.eg/pdfs/HE\%20Klaus\%20Ebermann,\%20Former $\% 20$ Ambassador $\% 20 \mathrm{of} \% 20$ the $\% 20$ European $\% 20$ Commission\%20Delegation $\% 20$ at \%20BUE.pdf (retrieved 05.09.2011); HAMBURG CHAMBER OF COMMERCE, The Hamburg Summit: China Meets Europe 2004: Speakers, http://www.hamburg-summit.com/looking-back/ hamburg-summit-china-meets-europe-2004/speakers-2/ (retrieved 05.09.2011). 
related to environmental fields. Ebermann and his team also pushed for space technology cooperation, a much more sensitive area. ${ }^{43}$

Although the premises of the Commission Delegation appeared rather modest and grey, ${ }^{44}$ the cooperation and coordination work that went on inside was intense and manifold. As the Constitutional Treaty took shape, there was a clear prospect that the Commission's missions would be transformed into Union Delegations. As previously discussed, the Delegation in Beijing already functioned as a representation of the Union in many ways. Nevertheless, it was now clear that it would soon officially represent the EU as a whole. At that time, not only the Chinese authorities and the business community but also the general public became more aware of the European Union. Apart from China's WTO accession, the introduction of the Euro in 2002 was central in this regard. Accordingly, the role of the EU Ambassador as a middle man in EU-China public diplomacy increased, too.

Given the EU's profile in trade matters, the expectations on the part of China were high that the EU, and thus the Commission Delegation, would emerge as a unifying actor in political terms, too. Due to the nature of CFSP, the Delegation could not live up to these expectations. Ambassador Ebermann publicly clarified that the EU did not just take away all sovereignty from its nation-states. ${ }^{45}$ Respectively, the Commission Delegation complemented the work of the local member state embassies instead of interfering in their competence areas. This distinction became more blurred under the following Ambassador.

\section{5-2010: Head of Delegation Serge Abou}

During Serge Abou's ambassadorial term in Beijing the transformation of Commission Delegations into European Union Delegations took place. Having served in the Commission since 1974, Serge Abou belongs to the same generation of EU officials as Klaus Ebermann and Endymion Wilkinson. Differently from his predecessors, he has a background in mathematics and econometrics. Accordingly, he started his career

43. China, EU to Enhance Cooperation in 2002, in: People's Daily, 03.01.2002, http://spanish.china.org.cn/english/investment/24678.htm (retrieved 05.09.2011); CHINAHIGHTECH.com, [European Commissioner for Research Visits Tsinghua to Inspect Environmentally Friendly Electric Cars], 14.04.2004, http://www.chinahightech.com/views_news.asp?Newsid=3393833333 (retrieved 05.09.2011); [EU and China Discuss Sustainable Development Strategy], in: People's Daily, 29.08.2011, http://www.envir.gov.cn/info/2001/8/829631.htm (retrieved 05.09.2011); Xinhua, EU Helps Liaoning Tackle Environmental Problems, 11.09.2002, http://china.org.cn/english/China/ 42715.htm (retrieved 05.09.2011); Agence France Presse, China Signs Agreement with EU on Galileo Project, 30.10.2003, http://www.spacedaily.com/2003/031030124730.ppien2mq.html (retrieved 05.09.2011).

44. [EU ambassador claimed middleman], in: Life Week, July 2001, http://www.qikan.com.cn/Article/ slzk/slzk200130/slzk20013008.html (retrieved 05.09.2011).

45. K. EBERMANN, Speech at Peking University, in Beijing, 23.10.2002, http://www.aisixiang.com/ data/2020.html (retrieved 05.09.2011). 
in the Directorate General (DG) for Economic and Monetary Affairs. Thereafter, he was entrusted with a key position in the DG Development. Furthermore he was Director-General for External Relations and Director for Trade Defence Policy. Similar to his predecessors, he also served in the executive floor of the Commission. ${ }^{46}$

Abou's experience in a variety of thematic fields was certainly advantageous to cover the increased range of areas that the Commission Delegation in Beijing was working on. These were notably trade and investments and "hundreds of projects" in research and higher education cooperation. Environment, energy and climate policy remained "highly visible" in China, too, despite the modest role of the EU at the Copenhagen Climate Conference in 2009. Some development projects were implemented but with a decreasing tendency. Given the EU's growing visibility, public diplomacy had become a major task. Ambassador Abou was frequently present in the Chinese media. In this context, a central project organised by the Delegation was the EU's pavilion at the world exhibition 'EXPO' in Shanghai.

Most time-consuming was the organisation of the many high-level visits of EUand PRC-officials and politicians, who now eagerly queued to visit Beijing. Respectively, reporting on China and maintaining good relations with the Chinese authorities became even more important. Interestingly, this was rather similar compared to the work of the EU member states' embassies. In that sense, the Delegation's profile can be considered as classically diplomatic. There are both national and EU-diplomats who remind that bilateral issues between EU members and China were clearly dealt with by the member state embassies. Others consider this distinction increasingly blurred and thus questionable. The Delegation's human resource development during Abou's time provides evidence for the further penetration of the Delegation into traditional diplomacy. Although the majority of new staff supported the trade section, an area of clear Union-competence, the political section was reinforced, too. ${ }^{47}$

Serge Abou's term is particularly relevant as it marks the transition for his Delegation from a mere representation of the Commission to a European Union Delegation. Serge Abou was the first Head of Delegation who officially carried the title 'Ambassador of the European Union to China'. Only 54 out of all full EU Delegations

46. Salzburg Global Seminar, China: The New Global Economic Engine? Profiles, 05.-10.12.2010, http://www.salzburgglobal.org/current/includes/FacultyPopUp.cfm?IDSPE-

CIAL_EVENT $=1180 \& I D R e c o r d s=117901$ (retrieved 05.09.2011).

47. Email correspondence with a European diplomat on July 8, 2011, in Beijing; Interview with a Chinese diplomat on July 19, 2011, in Beijing; See also L. GROEN, A. NIEMANN, EU Actorness and Effectiveness Under Political Pressure at the Copenhagen Climate Change Negotiations, Conference Paper, 12th European Union Studies Association Conference, Boston, 03.-05.03.2011, http:// euce.org/eusa/2011/papers/5i_groen.pdf (retrieved 05.09.2011); EU Delegation to China and Mongolia, Roof Goes on EU Belgian Pavilion for Shanghai Expo; Veil Comes off on Exciting EU Exhibit, 13.11.2009, http://eeas.europa.eu/delegations/china/press_corner/all_news/news/ 2009/20091113_01_en.htm (retrieved 06.09.2011); Interviews with European diplomats between October and November 2010. 
worldwide took over the Lisbon-tasks already in January $2010 .{ }^{48}$ Most of them were located in Africa. In order not to diminish the profile of the Spanish Presidency of the EU Council, Delegations to former Spanish colonies or to third countries with whom an EU-summit was scheduled were exempt from the early transformation. This shows that the member states were wary of allowing a quick Lisbon-takeover by Delegations in strategically important places. Interestingly, the PRC was the notable exception to that rule. There are two main reasons why the Beijing Delegation was transformed early. First, the team in Beijing simply was "ready", given its size and its expertise. Secondly, HR/VP Ashton sought to demonstrate a common European voice towards the PRC so as to push the EU-China strategic partnership. ${ }^{49}$

When it comes to the transition from the Commission- to the Union Delegation, the incremental spillover mechanism is again very visible. Only since Lisbon the Head of the Delegation in Beijing was officially mandated to speak on behalf of the EU-27. ${ }^{50}$ De facto, he did so before, e.g. by accompanying the Ambassador of the member state in charge of the rotating EU Council Presidency to meetings with the Chinese authorities, thereby "inspiring [the national Ambassador] what [...] to say". In that sense, Abou can be viewed as the "animator of [the] circle of Ambassadors largely before being their Chairman".

The Union's member state diplomats in Beijing welcomed that the EU took "the responsibility of the coordination and representation of Europe". Key motives were their busy bilateral schedules and the EU Delegation's professionalism. Another factor was the location. In contrast to e.g. Washington, relations with Beijing are in constant flux. Also, no member state has a very loaded history with China as for instance the former colonies have. This could not do away with unanimous decision making in CFSP or with the disunity on matters such as the arms embargo and the market economy status. Nevertheless, it relativises these two issues and the related prophecies of doom that the EU is not and will never be capable of constructing a 'common vision' for Sino-European relations. ${ }^{51}$

The 14 different constellations of informal EU coordination meetings have been a practical means to discuss, coordinate and present a common position in Beijing. These are regularly scheduled meetings of diplomats from the EU Delegation and

48. A. RETTMAN, EU Commission 'Embassies' Granted New Powers, in: EUObserver, 21.01.2010, http://euobserver.com/24/29308 (retrieved 06.09.2011). Not all Union representations can be considered 'full Delegations' as some of them are led by a chargé d'affaires and are thus dependent on a neighbouring Delegation. Others may function similarly to full Delegations but carry a different name for political reasons, such as the 'European Union Technical Assistance Office' in Palestine. See: European Union, The Role of the Office of the European Union Representative, http://eeas.europa.eu/delegations/westbank/about_us/delegation_role/index_en.htm (retrieved 06.09.2011).

49. Interview with a European diplomat on October 7, 2010 , in Beijing; A. RETTMAN, Ashton Names EU Foreign-Service Priorities at Low-Key Launch Event, in: EUObserver, 02.12.2010, http://euobserver.com/18/31413 (retrieved 06.09.2011).

50. A. RETTMAN, EU Commission 'Embassies' Granted ..., op.cit.

51. Interviews with European diplomats between October and November 2010, in Beijing, and Email correspondence with a European diplomat on July 8, 2011; Interview with a European diplomat on October 7, 2010, in Beijing; P. DUCHATEAU, op.cit., p.10; J. FOX, F. GODEMENT, op.cit. 
from all 27 member state embassies in Beijing on various levels (i.e. Head of Mission, Deputy Head of Mission etc.) and concerning a diversity of thematic areas (i.e. trade counsellors, science and technology, etc.). Although the scheme has not been based on formal instructions from Brussels, it now reflects the Council working groups. Back in Pierre Duchâteau's time, only the Heads of Missions met regularly. ${ }^{52}$ When Serge Abou started off in Beijing, the scheme consisted of about five such groups. Already before Lisbon, the Commission Delegation was vital in providing expertise. Sometimes EU diplomats even acted as 'shadow-chairpersons'. Small member state embassies particularly benefited from this. Nevertheless, before Lisbon the meetings usually took place in the embassy of the member state that held the Council Presidency. Diplomats from that embassy set the agenda and chaired each meeting. When the Lisbon Treaty ended the rotating Presidency in third country capitals, these meetings were moved to the premises of the EU Delegation. Agenda-drafting as well as chairmanship are since then assumed by Union staff. ${ }^{53}$

Reflecting the level of EU integration back home, some meetings may take place in member state embassies and be chaired by national diplomats, such as the cultureor the consular affairs group. But for practical reasons these groups are also hosted by the EU Delegation. To discuss sensitive issues, political counsellors sometimes meet in the bigger member state embassies as the Delegation is not yet equipped with a 'quiet room'. This example indicates that the EU Delegation has not yet fully reached the status of a Union-mission in the post-Lisbon sense. Such missions do not only continue to deal with the Union's sectorial policies. They now have an official mandate to handle classical diplomacy, such as foreign and security issues, on an everyday basis. ${ }^{54}$ This is one of the central aspects being implemented under the next EU Ambassador, Markus Ederer.

\section{1-onwards: Head of Delegation Markus Ederer}

Markus Ederer's appointment as EU Ambassador to China marks a sea change in the development of the EU's diplomatic service. He is among the first EU Ambassadors that have been selected by HR/VP Ashton under the new Lisbon rules. ${ }^{55}$ The most remarkable innovation is the integration of the national foreign services within the EEAS. This is implemented through the recruitment of at least one third of diplomats from the member states' diplomatic corps instead of the European Commission.

Markus Ederer is a high-ranking national diplomat who served from 1990 until 2010 in the German Federal Foreign Office. In contrast to his predecessors, he is far

52. P. DUCHATEAU, op.cit., p.11.

53. Interviews with European diplomats between October and November 2010, in Beijing.

54. Telephone interviews with European diplomats between April and July 2011.

55. T. VOGEL, Ashton Names EU Ambassadors, in: European Voice, 15.09.2010, http://www.europeanvoice.com/article/2010/09/ashton-names-eu-ambassadors/68862.aspx (retrieved 07.09.2011). 
from retirement and is among the younger European Ambassadors posted in Beijing. Similar to the majority of his predecessors, Beijing is Ederer's first ambassadorial post. German media rejoiced that with him, for the first time in history, the European Union has an own Ambassador to China. In legal terms this is correct. However, we know from the above analysis that all previous Heads of Delegation in Beijing have already been referred to as "EU Ambassadors". Ederer's Curriculum Vitae gives evidence of his professionalism as a diplomat also in a European context. He worked in Brussels for three years as the Head of Cabinet in charge of coordinating the Stability Pact for South Eastern Europe. Nevertheless, especially small member states may have been sceptical regarding Ashton's choice for a national diplomat from a big member state to represent the Union in China. After all, there have been instances when large member states, sometimes together with the Commission Delegation, have gone their own way in Beijing. ${ }^{56}$

The current Ambassador and his team are very conscious of the new presidential responsibility. They need to strike a delicate balance. On the one hand, the EU Delegation has a clear Treaty-based mandate to coordinate European diplomacy and to speak for the Union as a whole. On the other hand, EU diplomats in Beijing are careful not to claim a new leadership role at the expense of the member states. As a result, the new EU Ambassador seeks the role of a 'Chief Facilitating Officer' of all member states' interests. This is in line with the new role of the President of the EU Council. In order to do so, the EU Delegation team strives for a more transparent and "bottomup" style of cooperation with the local member state embassies. This is particularly necessary when coordinating CFSP in Beijing as the unanimity principle remains in place. Practically, information sharing and common "local assessments on particular subjects should be promoted as much as possible". Notwithstanding these efforts, the EU Delegation is in charge, even to the extent that embassies sometimes take over reports drafted by the Delegation. Another method favouring team-work, would consist of a modularised analysis where the EU Delegation would provide the main text and member state embassies would add specific aspects, depending on their expertise. In some areas, this method is already used. Not only does this imply a certain reversal of the EU turning into a principal rather than remaining the member states' agent. Also, smaller national embassies in terms of human resources may be the mid- to

56. Körber-Stiftung, Bergedorfer Gesprächskreis, Teilnehmer: Dr. Markus Ederer, Vita, http:// www.koerber-stiftung.de/internationale-politik/bergedorfer-gespraechskreis/teilnehmer/teilnehmer-detail/vita/ederer.html (retrieved 07.09.2011); EU Delegation to China and Mongolia, Curriculum Vitae Dr. Markus Ederer, http://eeas.europa.eu/delegations/china/documents/about_us/ me_cv_en.pdf (retrieved 07.09.2011). See also F. AUSTERMANN, Political Theory versus Diplomatic Practice: Bridging the Sovereignty-Gap of EU-China Relations, in: EU External Affairs Review, July 2011, p.57; Von Rimscha wird Planungschef im Auswärtigen Amt, in: Tagesspiegel, 17.12.2010, http://www.tagesspiegel.de/politik/von-rimscha-wird-planungschef-im-auswaertigenamt/3627776.html (retrieved 07.09.2011); Auswärtiges Amt, Pressemitteilung: Europäischer Auswärtiger Dienst gibt Europa in der Welt eine Stimme, 01.12.2010, http://www.auswaertiges-amt.de/ DE/Infoservice/Presse/Meldungen/2010/101201-EAD.html (retrieved 07.09.2011); Interviews with European diplomats between October and November 2010, in Beijing. 
long-term consequence of this evolution. In any event, this development indicates a big step in centralising diplomacy at the EU-level..$^{57}$

The EU Delegation's role vis-à-vis the EEAS centre in Brussels is strengthened as well. Expertise that used to be considered technical before is now being politicised. As a European diplomat puts it, more information 'travels in a Maybach rather than by bike from Beijing to Brussels': instead of a simple email, selected information is encrypted through the Ambassador's office and directly delivered to Ashton's, Barroso's and van Rompuy's desks. While preparing the 2011 EU-China summit, ${ }^{58}$ certain items were thus put high up on the agenda. Consequently, the Beijing Delegation becomes a key shaper of EU-China relations. To accomplish these tasks, the size of the political section has doubled. The Delegation's profile is also strengthened concerning the Union's representation to the Chinese authorities. It now conducts diplomatic démarches in the name of the EU. The MOFA addresses the Delegation for all EU-related matters and asks to pass on the message to member state embassies, to the detriment of the embassy of the country that holds the EU Council Presidency back in Europe. Depending on the Ambassador's ambition, that embassy still organises events, but these are "second-tier" and must be coordinated with the EU Delegation. In the MOFA's perception, this has considerably increased coherence of the EU in China as the Presidency's face does not change every six months anymore. Since personal relationships are particularly vital in the Chinese context, the new Lisbon-rules are promising to develop 'one European voice in Beijing'. Still, a Chinese diplomat has also observed an incremental change: after all, the previous Ambassador Abou already coordinated on all policy-fronts. ${ }^{59}$

Raising the Delegation's political profile, Markus Ederer was quick to take action in human rights matters, the most sensitive issue in China-EU relations. Only one month after his arrival in Beijing, he spoke out against "the physical obstruction and detention" of journalists during the so-called 'Jasmine-walks' which supported the

57. Telephone interview with a European diplomat on July 12, 2011; Interview with a Chinese diplomat on July 19, 2011, in Beijing; Interview with a European diplomat on July 22, 2011, in Beijing; EUROPEAN UNION, Consolidated Versions of the Treaty on European Union ..., op.cit., Art. 15(6c) and Art. 24(1).

58. Due to the number of summits to deal with the European debt crisis the EU-China summit was postponed from October 2011 to February 2012. See EUROPEAN COUNCIL, EU-China Summit Postponed, PRES/11/384, 21 October 2011, http://europa.eu/rapid/pressReleasesAction.do?reference $=$ PRES/11/384\&type $=$ HTML (retrieved 14.05.2012); COUNCIL OF THE EUROPEAN UNION, European Union Fact Sheet: EU Relations with China, 14 February 2012, http://www.consilium.europa.eu/uedocs/cms_data/docs/pressdata/EN/foraff/127836.pdf (retrieved 15.05.2012).

59. Interviews with European diplomats between October and November 2010 and on July 22, 2011, in Beijing; Interview with a Chinese diplomat on July 19, 2011, in Beijing. See also K. HWANG, Face and Favour. The Chinese Power Game, in: American Journal of Sociology, 4(1987), pp. 944-974. 
democratisation movements in Arabic countries. ${ }^{60} \mathrm{~A}$ few weeks later, he protested against the detention of the Chinese artist Ai Weiwei. ${ }^{61}$

The EU's role in security policy and defence cooperation is another sensitive issue. Despite a clear demand from the Chinese side, controversy prevails among EU members. In the White Paper on China's National Defence in 2010, the Chinese government explicitly states that it "explore[s] ways to develop military ties with [...] the EU'. Integration prospects in the 'highest' of politics areas, defence, remain modest, also after Lisbon. Nevertheless, regular consultation on crisis management between the EU and China are now part of the EU Delegation's portfolio. Practically, the Delegation seeks closer ties with the PRC's military personnel and coordinates with member states' embassies in an informal way, e.g. through ad hoc meetings, on relevant security issues. Through this informal working mode, the added value of security cooperation and coordination via the EU and its Delegation shall be demonstrated. From the Delegation's standpoint, it would be desirable to appoint a fullyfledged security advisor in order to achieve "symmetric access to information between Beijing and Brussels". After all, "[w]ith no uniform here [the PRC's Defence Ministry] will always be tempted to talk to uniforms from [the member states] first. This does not serve the EU interest". ${ }^{2}$

Overall, the above analysis shows that the EU Delegation in Beijing has developed into the key local player in both internal coordination of EU Diplomacy towards China and regarding external representation towards the Chinese authorities. This development testifies to the widening and deepening of EU integration even for diplomatic representation, the supposedly last stronghold of high politics. Nevertheless, there are still limits in terms of speaking with "one voice in Beijing" which are addressed in the final section.

60. EU Delegation to China and Mongolia, Statement by the European Union, 28.02.2011, http:// eeas.europa.eu/delegations/china/press_corner/all_news/news/2011/20110228_01_en.htm (retrieved 08.09.2011); No Awakening, but Crush it Anyway, in: The Economist, 03.03.2011, http:// www.economist.com/node/18291529 (retrieved 08.09.2011).

61. EU Delegation to China and Mongolia, Statement by the Head of Delegation of the European Union to China on the Increasing Use of Arbitrary Detention in China, 05.04.2011, http://eeas.europa.eu/ delegations/china/press_corner/all_news/news/2011/20110405_01_en.htm (retrieved 08.09.2011); M. BRISTOW, Concern Mounts Over Missing Chinese Artist Ai Weiwei, in: BBC, 05.04.2011, http://www.bbc.co.uk/news/world-asia-pacific-12971879; Political Activism Cannot be a Legal Shield, in: Global Times, 08.04.2011, http://europe.chinadaily.com.cn/opinion/2011-04/09/content_12297862.htm (retrieved 08.09.2011).

62. Chinese Government's Official Web Portal, China's National Defence in 2010, http://www.gov.cn/ english/official/2011-03/31/content_1835499_11.htm (08.09.2011); Telephone interview with a European diplomat on July 12, 2011. 


\section{Conclusion, Limitations and Outlook}

As the biggest of the emerging economies and upcoming political powers, China is important to every EU member state. Thus, the new centre stage which the Delegation takes in EU-matters does not loosen the strong bilateral ties of the 27 member states of the European Union with the PRC. Several aspects support this view. Firstly, all 27 member states maintain a diplomatic presence in Beijing. The majority has consulates in other Chinese cities in addition. Secondly, despite tight budget constraints, especially in the current economic climate, none of the embassies in Beijing has experienced any downsizing. By contrast, most of them have even reinforced their human resources over the past years. ${ }^{63}$

As mentioned before, this is also the case for the CFSP. Despite the clearly upgraded political role, the EU Delegation cannot do away with either unanimity in CFSP or with the diverging interests of member states. This makes it difficult to speak always with one voice in Beijing. One example is Ambassador Ederer's protest against the detention of Ai Weiwei. All member state Ambassadors agreed on the text, but the Delegation could not speak on behalf of the whole EU in this matter. ${ }^{64}$ In a similar vein, it remains to be seen if the Delegation will eventually be provided with military staff. The fierce opposition of the UK against more EU-level centralisation in defence matters puts this into question. ${ }^{65}$

The division of labour between the EU and the member states in Beijing seems to work very well according to the PRC's Ministry of Foreign Affairs. At the same time, there is the impression that the work of the Delegation no longer seems really different from that of the national embassies. This implies a duplication of resources with the Delegation becoming the embassy of the "28th Member State" 66 instead of a force of centralisation. Some European diplomats entirely agree with this interpretation. As of yet, it is also still uncertain whether the new mix of EU-level and national diplomats will fuse the best of both worlds or whether it will accumulate all disadvantages instead. The temporary inclusion of national diplomats within the EEAS may be problematic as they remain fully affiliated to the national services.

This indicates a certain eagerness of member states to send 'their' top-diplomats to Beijing. As a result, Beijing has to deal with a very special situation: both the Head and the Deputy Head of the Delegation come from national services. In many other

63. B. HOCKING, D. SPENCE, op.cit., p.3; Z. BO, F.AUSTERMANN, EU Diplomacy After Lisbon: The Case of China. Embassy Staff Development in Beijing. Research Seminar at National University of Singapore, 07.12.2010, http://www.eucentre.sg/events/69/EUChina1_7.12.2010.pdf (retrieved 08.09.2011).

64. Interview with a European diplomat on July 22, 2011, in Beijing.

65. European Union Military Headquarters: Britain Says It Will Block Proposed Plans, in: The Huffington Post, 18.07.2011, http://www.huffingtonpost.com/2011/07/18/european-union-militaryheadquaters_n_901567.html (retrieved 21.09.2011).

66. I. GRÄSSLE, $\bar{A}$ Critical Analysis: The Creation of the European External Action Service, European Issue, in: FONDATION ROBERT SCHUMAN, Policy Paper, 94(14.02.2011), p.1, http:// www.robert-schuman.eu/doc/questions_europe/qe-194-en.pdf (retrieved 19.12.2011). 
places where a member state diplomat has become Head of Delegation, the Deputy is a Commission official. Leaving aside member state competition, this special situation in Beijing has resulted in considerable administrative obstacles. All Heads of EU Delegations have 'double-hats', just like HR/VP Ashton, meaning that they represent the EEAS as well as the European Commission. This is important because some parts of the European Commission have been integrated into the EEAS, such as DG Relex. The Commission however keeps responsibility over policy domains, such as development or trade. As a result, the EU Delegations are accountable to two institutions, the Commission and the EEAS. Consequently, the EU Delegation must keep the Commission finances and the EEAS' finances separate. ${ }^{67}$ If the Deputy Head comes from a national diplomatic service, he or she can only speak and act for the EEAS. The Head of Delegation can therefore not share responsibilities properly with his or her Deputy when implementing Commission projects. The problem of speaking with one voice is thus not only rooted in the diversity of the 27 member states. It also comes down to the diversity and changing power-geometry of the EU institutions in Brussels. To develop administrative processes and a working division of labour, the EEAS as a whole and the EU Delegations in particular need time, before they can work as smoothly as the long-established national diplomatic services. But after all, the defining characteristic of the EU is its diversity. Maybe a more appropriate and realistic goal for the EEAS and its Delegations should not necessarily be to speak with one voice. As a high-level European diplomat suggested, they should compose a common text with one melody. That way, the EU, its members and its institutions may sing the same song from the same sheet of music and, by all means, with several voices.

67. T. VOGEL, Ashton on Defensive Over EU's Diplomatic Service, in: European Voice, 26.01.2012, $\mathrm{http} / /$ www.europeanvoice.com/article/imported/ashton-on-defensive-over-eu-s-diplomatic-service/73094.aspx (retrieved 26.01.2012).http://www.bbc.co.uk/news/world-asia-pacific-12971879. 